\title{
Diabetic Foot Wounds: Which Patients are More Prone to Tetanus?
} Diyabetik Ayak Yarası: Hangi Hastalar Tetanoza Daha Yatkın?

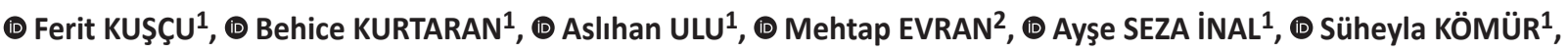 \\ (D) Salih ÇETINER ${ }^{3}$, (D) Yeşim TAŞOVA ${ }^{1}$ \\ ${ }^{1}$ Çukurova University Faculty of Medicine, Department of Infectious Diseases and Clinical Microbiology, Adana, Turkey \\ ${ }^{2}$ Çukurova University Faculty of Medicine, Department of Internal Medicine, Division of Endocrinology, Adana, Turkey \\ ${ }_{3}^{3}$ Çukurova University, Balcalı Hospital, Clinic of Basic Immunology, Central Laboratory, Adana, Turkey
}

\section{Abstract}

Introduction: Patients who have tetanus-prone wounds, diabetes mellitus, or chronic wounds are more likely to contract tetanus. In this study, we aimed to evaluate the tetanus immunization status of patients with diabetic foot wounds (DFW) and to determine factors that may predict insufficient immunity to tetanus.

Materials and Methods: Patients who presented to our outpatient clinics with DFW were included. Tetanus antibody levels below 0.1 IU/mI were defined as "no reliable protection" and levels of $0.1 \mathrm{lU} / \mathrm{ml}$ and above were defined as "reliable protection".

Results: Ninety-one patients were enrolled in the study, 66 (72.5\%) were male and the mean age was $62 \pm 11$ years. Sixty-five (71.4\%) of the patients had no reliable protection, while $26(28.6 \%)$ had reliable protection. Age, duration of diabetes mellitus, education level, and residency status were significantly different between the immune and nonimmune groups in univariate analysis. In the multivariate logistic regression analysis, age $\geq 65$ years [Odds ratio (OR): $8.33 ; 95 \%$ confidence interval $(\mathrm{Cl}): 2.03-34.16]$, diabetes mellitus duration $\geq 11$ years $(\mathrm{OR}$ : $6.52 ; 95 \% \mathrm{Cl}: 1.97-21.59)$, and lowest educational level (OR: 10.51; 95\% Cl: 1.61-68.52) were identified as independent predictors for insufficient tetanus immunity.

Conclusion: We found that elderly patients and patients with lower education have a very low rate of immunity against tetanus. Therefore, tetanus vaccination should be conducted in elderly patients with DFW.

Keywords: Vaccine, educational level, epidemiology, ELISA, Clostridium tetani

\section{Öz}

Giriş: Tetanoza meyilli yarası, diyabeti veya kronik yaraları olan hastaların tetanoza yakalanma ihtimali daha yüksektir. Bu çalışmada, diyabetik ayak yarası olan hastalarda tetanoza karşı bağışıklık durumunun araştırılması ve yetersiz immüniteyi öngördürebilecek faktörlerin araştırılması amaçlandı. Gereç ve Yöntem: Diyabetik ayak yarası ile polikliniklerimize başvuran hastalar çalışmaya dahil edilmiştir. Tetanoz antikor seviyelerinin 0,1 IU/mI'nin altında olması durumu yeterli bağışıklığın olmadığı; 0,1 IU/ml'nin üstünde tespit edilmesi durumunda ise bağışıklık yeterli olarak kabul edildi.

Bulgular: Doksan bir hasta çalışmaya dahil edildi ve 66'sı $(\% 72,5)$ erkekti. Yaş ortalaması $62 \pm 11$ yıldı. Altmış beş hastada (\%71,4) yeterli düzeyde koruyucu antikor yokken $26(\% 28,6)$ hastada vardı. Yaş, diyabet yaşı, eğitim seviyesi, yaşadığı bölge açısından tetanoza karşı bağışık olan ve olmayan iki grubun univariate analizinde, gruplar arasında istatistiksel olarak anlamlı farklılık mevcuttu. Lojistik regresyon analizinde ise yaş $\geq 65$ yıl olması [Odds oranı (OR): 8,33; \%95 güven aralığı (GA): 2,03-34,16], diyabet yaşının $\geq 11$ yıl olması $(0 R: 6,52 ; \% 95$ GA: 1,97-21,59) ve düşük eğitim seviyesi (OR: 10,51; \%95 GA: 1,61-68,52) yetersiz bağışıklığın öngördürücüsü faktörler olarak tespit edildi.

Sonuç: Çalışmamızda yaşlı ve düşük eğitim seviyesi olan hastaların tetanoza karşı çok düşük oranda bağışıklığa sahip olduklarını tespit ettik. Bu nedenle, diyabetik ayak yarası olan yaşlı hastalarda serolojik kontrol bakılmaksızın tetanoz aşılaması yapılmasını öneriyoruz.

Anahtar Kelimeler: Aşı, eğitim seviyesi, epidemiyoloji, ELISA, Clostridium tetani

Cite this article as: Kuşçu F, Kurtaran B, Ulu A, Evran M, Seza İnal A, Kömür S, Çetiner S, Taşova Y. Diabetic Foot Wounds: Which Patients are More Prone to Tetanus? Mediterr J Infect Microb Antimicrob. 2019;8:27. 


\section{Introduction}

Diabetic foot wound (DFW) is one of the important complications of diabetes mellitus (DM) and may significantly reduce quality of life ${ }^{[1]}$. Diabetics, patients with chronic wounds, and intravenous drug users are more prone to tetanus than other populations. The prevalence of DM among patients diagnosed with tetanus was reported as $15 \%$, nearly three times the average expected prevalence of DM in the United States ${ }^{[2]}$. There are several factors that lead to tetanus in a patient suffering from DFW. One of them is macrovascular or microvascular disease, which affects the delivery of immune cells to the wound and which can also create an anaerobic environment due to lower oxygen tensions in DFW. Gangrenous tissue is another factor that is frequently seen in DFWs and predisposes patients to tetanus ${ }^{[3,4]}$. Over $70 \%$ of all diagnosed tetanus infections occur in people over 50 years of age, and $11 \%$ of all tetanus cases were found in patients suffering from chronic wounds ${ }^{[5]}$.

In this study, we aimed to evaluate the tetanus immune status of patients with DFWs and identify factors which may predict insufficient immunity against tetanus.

\section{Methods}

\section{Study Settings and Patients}

The study was conducted between 01 January 2016 and 31 December 2016. Our hospital is a regional referral hospital with 1,200-bed capacity. Patients who were presented to the diabetic foot council of our hospital and were willing to take part in the study were included. During the study period, a total of 127 patients were evaluated by the council and 91 participated in the study. Diabetic foot wounds were classified according to the Wagner Classification ${ }^{[6]}$.

All patients provided written informed consent and the study was approved by the Local Ethics Committee of Çukurova University Medical Faculty (09.01.2016/49). All procedures followed were in accordance with the ethical standards of the responsible committee on human experimentation (institutional and national) and the 2008 revision of the Declaration of Helsinki ${ }^{[7]}$. Demographic characteristics of the patients were recorded and a standard questionnare was applied to all patients to collect a detailed diabetes and tetanus vaccination history.

\section{Serological Analysis}

Venous blood was drawn from all patients and centrifuged for 5 minutes at $3000 \mathrm{rpm}$; the resulting serum samples were stored at $-40{ }^{\circ} \mathrm{C}$ until testing. Tetanus antibody levels were measured using a commercial Clostridium tetani $5 \mathrm{~S}$ immunoglobulin $\mathrm{G}$ $(\mathrm{lgG})$ enzyme-linked immunosorbent assay (ELISA) kit (Novatec Immun Diagnostica GmBH, Germany) in the ELISA laboratory of our hospital. The results were evaluated according to levels previously defined by Schröder and Kuhlmann ${ }^{[8]}$. Antibody levels below $0.1 \mathrm{IU} / \mathrm{ml}$ were defined as "no reliable protection" and antibody levels of $0.1 \mathrm{IU} / \mathrm{ml}$ and above were defined as "reliable protection but may require booster dose." Antibody levels of $0.5 \mathrm{IU} / \mathrm{ml}$ and above were considered "reliable protection, no booster dose required" according to manufacturer suggestions. All patients were referred to their family physician to be evaluated for tetanus vaccination after clinical assessment and vaccinated if required.

\section{Statistical Analysis}

Statistical analysis was performed using MedCalc Statistical Software version 17.4 (MedCalc Software bvba, Ostend, Belgium) and SPSS version 20.0 (SPSS Inc., Chicago, IL, USA). Descriptive analyses were presented using percentages, median, minimum-maximum, means, and standard deviations. The variables were investigated using Kolmogorov-Smirnov test to determine whether they were normally distributed. Patients were divided into two groups depending on whether they had reliable protection against tetanus. The two groups were compared according to age, gender, diabetes duration, marital status, residency status (rural/urban), education level, previous history of DFW, whether they had received tetanus vaccination every 10 years, and their self-reported tetanus immunization status (fully covered, not covered, unknown). Receiver operating characteristic (ROC) curve analysis was used to detect a cutoff value for diabetes duration. Student's T-test for continuous variables and chi-square or Fischer's Exact test for discrete variables were used between groups for univariate analysis. For multivariate analysis, the possible predictive factors $(p<0.20)$ identified in univariate analysis were further entered into logistic regression analysis to determine the independent predictors of insufficient tetanus immunity. Hosmer-Lemeshow goodness-offit statistics were used to assess model fit. Spearman's test was used for correlation analyses between age and tetanus antibody titers. A $p$ value of less than 0.05 was considered statistically significant.

\section{Results}

\section{Demographics}

Ninety-one patients were enrolled to the study, 66 (72.5\%) were male and $25(27.5 \%)$ were female. Mean age was $62 \pm 11$ years. Seventy-two (79.1\%) of the patients lived in urban areas and 19 $(20.9 \%)$ in rural areas. Regarding marital status, $81(89 \%)$ of the participants were married and 10 (11\%) were single.

A total of 75 patients (82.4\%) were using insulin, $15(16.5 \%)$ were using an oral antidiabetic agent, and one patient (1.1\%) was not using any antidiabetic medicine. Mean diabetes duration was $15.3 \pm 8.2$ years. Sixty-eight patients (74.7\%) had one or more 
comorbidities concomitantly with diabetes and 23 patients (25.3\%) had no comorbidity other than diabetes. Comorbidities, Wagner classification, and wound locations of the patients are presented in Table 1. Forty-nine patients (53.8\%) had a history of previous DFW.

When asked about their tetanus immunization status, 79.1\% of the patients $(n=72)$ were unsure of their vaccination status, $14.3 \%(n=13)$ believed they were not covered, and 6.6\% $(n=6)$ believed they were covered. However, 97.8\% of the patients $(n=89)$ stated that they did not get vaccinated every 10 years. Only 20 patients $(22 \%)$ remembered being vaccinated with at least one dose of tetanus vaccine.

\section{Serological Results}

Using a cut-off value of $0.1 \mathrm{IU} / \mathrm{ml}$ for reliable protection against tetanus, 65 patients (71.4\%) had no reliable protection and 26 $(28.6 \%)$ had reliable protection. Only 10 patients $(11 \%)$ had tetanus antibody levels above $0.5 \mathrm{lU} / \mathrm{ml}$ and did not require booster vaccination. However, at least one dose of booster vaccination was required for the rest (89\%) of the patients, even though some of them had reliable protection ( $>0.1 \mathrm{IU} /$

Table 1. Patients' comorbidities, Wagner classification, and wound locations

\begin{tabular}{l|c|c}
\hline Comorbidities & $\mathbf{n}$ & $\%$ \\
\hline CVD & & \\
\hline CRF & 24 & 50.5 \\
\hline Hypertension & 21 & 26.3 \\
\hline COPD & 4 & 23.0 \\
\hline Wagner classification & & \\
\hline 1 & 16 & 17.6 \\
\hline 2 & 21 & 23.1 \\
\hline 3 & 27 & 29.7 \\
\hline 4 & 20 & 22 \\
\hline 5 & 7 & 7.7 \\
\hline Wound location & & \\
\hline Toe & 63 & 69.2 \\
\hline Calcaneal & 12 & 13.2 \\
\hline Plantar & 8 & 8.8 \\
\hline Dorsal & 8 & 8.8 \\
\hline
\end{tabular}

CVD: Cardiovascular disease, CRF: Chronic renal failure, COPD: Chronic obstructive pulmonary disease $\mathrm{ml}$ ). When assessing the association between booster dose requirement and patients' self-reported tetanus immunity, booster dose vaccination requirement was significantly higher in patients who stated that they were not covered or did not know their tetanus vaccine coverage than among those who stated that they were fully covered against tetanus $(p<0.002)$ (Table 2).

Spearman's correlation analysis showed a significant negative correlation between age and tetanus antibody titers ( $r=-0.393$, $\mathrm{p}<0.0001$ ) (Figure 1). The patients' protection rates that were determined according to age (in decade units) were as follows: $<39$ years: $100 \%$; $40-49$ years: $62.5 \%$; $50-59$ years: $35.3 \%$; $60-$ 69 years: $28.2 \%$; and $\geq 70$ years: $0 \%$ (Figure 2 ).

Patients were divided into two groups based on whether or not they had reliable protection against tetanus. Factors including age, diabetes mellitus duration, education level, and residency status were significantly different between the two groups (Table 3 ). In ROC analysis, 11 years was determined as the cutoff value for diabetes duration (AUC: 0.641, $p=0.033$ ).

In the multivariate logistic regression analysis, age $\geq 65$ years [Odds ratio (OR): 8.33; 95\% confidence interval (CI): 2.03-34.16], diabetes duration $\geq 11$ years (OR: $6.52 ; 95 \% \mathrm{Cl}: 1.97-21.59$ ) and lowest education level (OR: 10.51; 95\% Cl: 1.61-68.52) were identified as independent predictors for insufficient tetanus immunity (Table 4).

\section{Discussion}

Diabetes is considered as e of the greatest emerging threats to human health in the $21^{\text {st }}$ century. Besides the classical complications of the disease, diabetes has been associated with reduced $T$ cell response, neutrophil dysfunction, and disorders of humoral immunity ${ }^{[9,10]}$. A study regarding tetanus epidemiology between 1972 and 2001 indicated a higher risk of tetanus in diabetic patients. Overall, diabetic patients are 3.2 times more likely to contract tetanus than nondiabetic patients. In addition, case mortality is higher in diabetic patients than nondiabetics ( $44 \%$ vs. $28 \%$ ). Rather than the more typical puncture or cut, these patients had chronic wounds, such as an ulcer or gangrene ${ }^{[11]}$. In various studies carried out in North America, DFW, and gangrene represented a main risk factor, accounting for up to $25 \%$ of all tetanus infections ${ }^{[3]}$. In another case series of 25 tetanus patients from Uganda, the most

Table 2. Patients' self-reported tetanus immunization status and their booster vaccination requirements

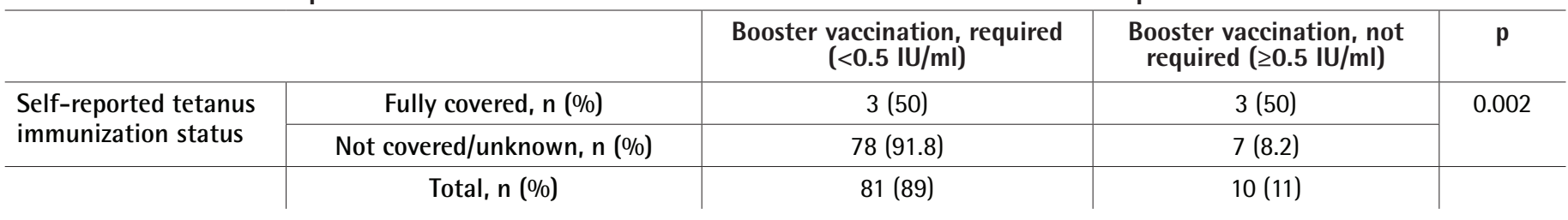




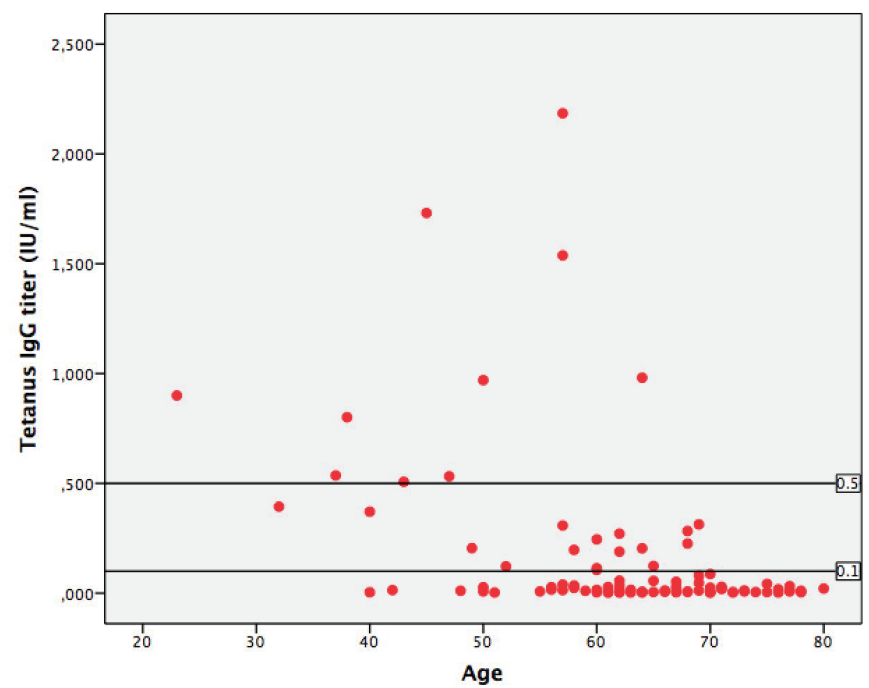

Figure 1. Age and tetanus immunoglobulin G level correlation graph $(r=-0.393, p<0.0001)$

IgG: Immunoglobulin G

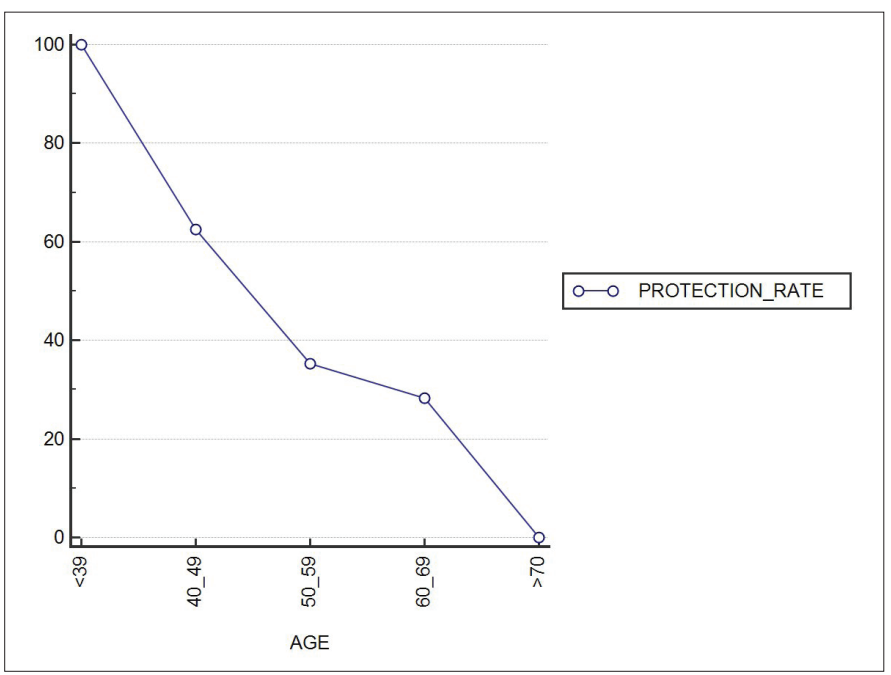

Figure 2. Tetanus protection rates of the patients according to age (by decade)

common tetanus entry wounds were due to traffic accidents, followed by DFWs ${ }^{[12]}$. In light of these epidemiological data, it is expected that older patients with diabetes are more prone to tetanus. Unsurprisingly, if the patients have chronic wounds like DFWs, the risk will increase. Due to the higher mortality rate, we wanted to investigate tetanus immunization status of our patients suffering from DFW and we found a very low rate $(28.6 \%)$ of reliable protection against tetanus in these patients.

The site of entry is known in more than 90\% of patients presenting with tetanus and lower limb injuries, and wounds are one of the main causes of tetanus ${ }^{[13,14]}$. Because of the necrotic and dirty nature of DFWs, it may provide a suitable environment for $C$. tetani spores. Therefore, it is essential to know the tetanus immunity status of DFW patients.
Table 3. Univariate analysis of variables for tetanus immunity

\begin{tabular}{|c|c|c|c|}
\hline Characteristics & $\begin{array}{c}\text { Immune } \\
\text { patients } \\
(\geq 0.1 \mathrm{IU} / \mathrm{ml}) \\
(\mathrm{n}=\mathbf{2 6})\end{array}$ & $\begin{array}{c}\text { Nonimmune } \\
\text { patients } \\
(<0.1 \mathrm{IU} / \mathrm{ml}) \\
(\mathrm{n}=65)\end{array}$ & p \\
\hline \multicolumn{4}{|l|}{ Age } \\
\hline$<65$ years, $\mathrm{n}(\%)$ & $22(43.1)$ & $29(56.9)$ & 0.0001 \\
\hline$\geq 65$ years, $\mathrm{n}(\%)$ & $4(10.0)$ & $36(90.0)$ & \\
\hline Diabetes duration & & & 0.003 \\
\hline <11 years, $\mathrm{n}(\%)$ & $16(47.1)$ & $18(52.9)$ & \\
\hline$\geq 11$ years, $n(\%)$ & $10(17.5)$ & $47(82.5)$ & \\
\hline \multicolumn{4}{|l|}{ Gender } \\
\hline Male, n (\%) & $21(31.8)$ & 45 (68.2) & 0.265 \\
\hline Female, n (\%) & $5(20.0)$ & $20(80.0)$ & \\
\hline \multicolumn{4}{|l|}{ Marital status } \\
\hline Married, n (\%) & $25(30.9)$ & $56(69.1)$ & 0.271 \\
\hline Single, n (\%) & $1(10.0)$ & $9(90.0)$ & \\
\hline \multicolumn{4}{|l|}{ Residency status } \\
\hline Urban, n (\%) & $24(34.3)$ & $46(65.7)$ & 0.028 \\
\hline Rural, n (\%) & $2(9.5)$ & $19(90.5)$ & \\
\hline \multicolumn{4}{|l|}{ Education level } \\
\hline $\begin{array}{l}\text { Primary/secondary school, } \\
\mathrm{n}(\%)\end{array}$ & $20(24.7)$ & $61(75.3)$ & 0.029 \\
\hline $\begin{array}{l}\text { High school/university, } \\
\mathrm{n}(\%)\end{array}$ & $6(60)$ & $4(40)$ & \\
\hline \multicolumn{4}{|l|}{$\begin{array}{l}\text { Vaccination every } 10 \\
\text { years }\end{array}$} \\
\hline Yes, n (\%) & $1(50)$ & $1(50)$ & 0.492 \\
\hline No, n (\%) & $25(28.1)$ & 64 (71.9) & \\
\hline \multicolumn{4}{|l|}{$\begin{array}{l}\text { Previous diabetic foot } \\
\text { wounds }\end{array}$} \\
\hline Yes, n (\%) & $15(30.6)$ & $34(69.4)$ & 0.642 \\
\hline No, n (\%) & $11(26.2)$ & 31 (73.8) & \\
\hline \multicolumn{4}{|l|}{$\begin{array}{l}\text { Self-reported tetanus } \\
\text { immunization status }\end{array}$} \\
\hline Fully covered, n (\%) & $3(50)$ & $3(50)$ & 0.461 \\
\hline Not covered, n (\%) & $4(30.8)$ & $9(69.2)$ & \\
\hline Unknown, n (\%) & $19(26.4)$ & $53(73.6)$ & \\
\hline
\end{tabular}

Table 4. Predictive factors for insufficient immunity against tetanus

\begin{tabular}{l|c|c|c}
\hline & Odds ratio & $\mathbf{9 5 \%} \mathbf{C l}$ & $\mathbf{p}$ value \\
\hline Age $\geq \mathbf{6 5}$ years & 8.33 & $2.03-34.16$ & 0.003 \\
\hline Diabetes duration $\geq 11$ years & 6.52 & $1.97-21.59$ & $\mathbf{0 . 0 0 2}$ \\
\hline Rural residency & 5.67 & $1.00-32.16$ & 0.050 \\
\hline Lower education level $^{*}$ & 10.51 & $1.61-68.52$ & $\mathbf{0 . 0 1 4}$ \\
\hline
\end{tabular}

$\mathrm{Cl}$ : Confidence interval, *Primary and secondary school

It is known that the majority of tetanus cases involve people over 60 years of age in developed countries ${ }^{[15]}$. A study conducted by Srivastava et al. ${ }^{[1]]}$ revealed that $52 \%$ of all tetanus cases were 
in patients over age 60 , and $74 \%$ of all deaths occurred in this age group. In another study including 117 tetanus patients from Turkey, the mean age was $58 \pm 16$ and 62 patients (53\%) were over 60 years old ${ }^{[16]}$. Because of the high incidence of tetanus among elderly patients, seroepidemiological studies should be performed periodically to investigate tetanus immunity, and vaccination campaigns should be initiated. The rate of tetanus immunity differs from region to region due to countries' varying vaccination policies. In the United States, the proportion of adults reporting having received any tetanus toxoid-containing vaccination during the past 10 years was $61.6 \%$ overall for adults aged $\geq 19$ years, and $56.9 \%$ for adults aged $\geq 65$ years ${ }^{[17]}$. In a study from Iran, the immunity rate was reported as 35\% in patients over 50 years of age ${ }^{[18]}$. In various studies from Turkey, immunity rates were reported to range between $15.7 \%$ and $33.8 \%$ in elderly patients $\mathrm{s}^{[19-22]}$. In the present study, we found an immunity rate of $28.6 \%$ overall and $10 \%$ for patients who were $\geq 65$ years old, consistent with previous studies in Turkey. In addition to older age, we also found that low education level might predict insufficient tetanus immunity, which was also compatible with other studies ${ }^{[22,23]}$.

In Turkey, the National Vaccination Campaign accelerated tetanus immunization among children in 1985. The rate for three doses of primary vaccination increased from 20-30\% to over $80 \%$ with the campaign and thereafter the rate was maintained between nearly $70 \%$ and over $80 \%$ as a nationwide average ${ }^{[24]}$. Turkish people who were born before 1985 are more likely to have incomplete primary vaccination series against tetanus. Therefore, all physicians should know when childhood national vaccination campaigns against tetanus were launched in their country. This information may help physicians decide whether to administer only one tetanus booster dose or the three-dose primary vaccination series in adult patients.

There are numerous studies in the literature concerning immunity rates against tetanus in various patient populations, but studies including patients suffering from DFW or chronic leg ulcers are very limited. Korber et al. ${ }^{[5]}$ reported that $47 \%$ of all patients suffering from chronic leg ulcers showed an insufficient tetanus antibody concentration, and their subanalysis revealed that $70 \%$ of patients aged over 80-year-old had insufficient protection against tetanus. In the present study, we found that sufficient protection rates in DFW patients decreased with increasing age, as in the aforementioned study. Another study conducted by Farnworth et al ${ }^{[25]}$ included 100 patients with chronic leg ulcer, nearly half of whom had DM. When the patients were asked about their tetanus immunization status, $48 \%$ were unsure of their status, 30\% believed that they were not covered, and $22 \%$ believed that they were covered. After confirming with vaccination records, they found that $43 \%$ of the patients were not covered, while $33 \%$ of them were covered. In contrast, we determined sufficient immunity in only $50 \%$ of the patients who thought they were covered, $30.8 \%$ of the patients who thought they were not covered, and $26.4 \%$ of the patients who were unsure of their status. In addition, only $22 \%$ of the patients remembered being vaccinated at least once and $97.8 \%$ of the patients reported not receiving a routine tetanus booster every 10 years. All of these results suggest high level of unawareness regarding tetanus vaccination in patients and low routine adult vaccination rates.

The medical records of adult vaccination were generally poor, and although patients claimed to be immune, half of them did not have sufficient immunity against tetanus. Our data suggest that we should not rely on verbal claims if the records are not complete. A booster dose was required for the $89 \%$ of the patients who were not vaccinated or did not know about their vaccinations status. Therefore, we propose that all patients presenting with DFWs should be vaccinated with at least one dose of tetanus vaccine without testing for $\lg \mathrm{G}$ status and a three-dose primary vaccination schedule should be considered for those who do not know their vaccination history and whose medical records are incomplete or inaccessible.

We did not find any difference in tetanus immunity between patients who had a history of previous DFW and those who did not. This was thought to be because tetanus vaccination did not come to the physicians' minds when treating the earlier DFWs, so the patients were not vaccinated. We believe that this is evidence of the low awareness level of both patients and treating doctors in terms of tetanus vaccination.

One of the limitations of this study was the small number of patients and the fact that it was conducted in only one institute. However, it was encouraging to find the results were similar to larger and more inclusive epidemiologic studies about adult immunization rates against tetanus.

\section{Conclusion}

As the immunity rate against tetanus decreases with advanced age, DM duration, and lower education in DFW patients, attending physicians should immunize these patients for tetanus at the first possible opportunity in addition to the other required vaccines for DM (pneumococcal, influenza, hepatitis $B$, and zoster vaccine).

\section{Acknowledgements}

We would like to thank Nurses Sema İnce and Havva Özkılıç, and Dr. Cemile Aslan for their valuable assistance with data collection.

\section{Ethics}

Ethics Committee Approval: This study was approved by the Local Ethics Committee of Çukurova University Medical Faculty (09.01.2016/49). 
Informed Consent: Informed consent was filled out by all participants.

Peer-review: Externally and internally peer-reviewed.

Medical Practices: F.K., S.Ç., Concept: F.K., Design: F.K., B.K., Data Collection or Processing: F.K., M.E., A.U., S.K., Analysis or Interpretation: F.K., A.S.I., Literarute Search: F.K., Y.T., Writing: F.K., B.K., M.E., A.S.i.

Conflict of Interest: No conflict of interest was declared by the authors.

Financial Disclosure: This work was supported by the Scientific Research Fund of the Çukurova University (project number: TSA-2016-5877).

\section{References}

1. Markakis K, Bowling FL, Boulton AJ. The diabetic foot in 2015: an overview. Diabetes Metab Res Rev. 2016;32:169-78.

2. Centers for Disease Control and Prevention (CDC).Tetanus surveillance --United States, 2001-2008. MMWR Morb Mortal Wkly Rep. 2011;60:365-9.

3. Rogers LC, Frykberg RG. Tetanus prophylaxis for diabetic foot ulcers. Clin Podiatr Med Surg. 2006;23:769-75.

4. Reiber GE, Vileikyte L, Boyko EJ, del Aguila M, Smith DG, Lavery LA, Boulton AJ. Causal pathways for incident lower-extremity ulcers in patients with diabetes from two settings. Diabetes Care. 1999;22:157-62.

5. Korber A, Graue N, Rietkotter J, Kreuzfelder E, Grabbe S, Dissemond J. Insufficient tetanus vaccination status in patients with chronic leg ulcers. Results of a prospective investigation in 100 patients. Dermatology. 2008;217:69-73.

6. Samson 0. Oyibo, Edward B. Jude, Ibrahim Tarawneh, Hienvu C. Nguyen, Lawrence B. Harkless, Andrew J.M. Boulton.A Comparison of Two Diabetic Foot Ulcer Classification Systems. Diabetes Care. 2001;24:84-8.

7. World Medical Association (WMA). World Medical Association Declaration of Helsinki: Ethical Principles for Medical Research Involving Human Subjects. JAMA. 2013;310:2191-4.

8. Schröder JP, Kuhlmann WD. Preventive tetanus immunization and avoidance of side effects of booster immunization. Dtsch Med Wochenschr. 1992;117:1903-6.

9. Geerlings $\mathrm{SE}$, Hoepelman AI. Immune dysfunction in patients with diabetes mellitus (DM). FEMS Immunol Med Microbiol. 1999;26:259-65.

10. Muller LM, Gorter KJ, Hak E, Goudzwaard WL, Schellevis FG, Hoepelman AI, Rutten GE. Increased risk of common infections in patients with type 1 and type 2 diabetes mellitus. Clin Infect Dis. 2005;41:281-8.

11. Srivastava P, Brown K, Chen C, Kretsinger K, Roper M. Trends in tetanus epidemiology in the United States, 1972-2001. Presented at the 39th National Immunization Conference, Washington, D.C., March 21-24, 2005.
Last accessed date: 28.05.2017. Available from: http://cdc.confex.com/cdc/ nic2005/techprogram/paper_7813.htm

12. Nanteza B, Galukande $M$, Aceng J, Musinguzi J, Opio A, Mbonye AK, Mukooyo E, Behumize $P$, Makumbi $F$. The burden of tetanus in Uganda. Springerplus. 2016;5:705.

13. Reddy P, Bleck TP. Clostridium tetani (Tetanus). In: Mandell GL, Bennett $\mathrm{JE}$, Dolin R (eds). Principles and Practice of Infectious Diseases, 7th ed. Philadelphia, PA: Elsevier, 2010:3091-6.

14. Dalal S, Samuelson J, Reed J, Yakubu A, Ncube B, Baggaley R. Tetanus Disease and Deaths in Men Reveal Need for Vaccination. Bull World Health Organ. 2016;94:613-21.

15. Dietz V, Galazka A, van Loon F, Cochi S. Factors affecting the immunogenicity and potency of tetanus toxoid: implications for the elimination of neonatal and non-neonatal tetanus as public health problems. Bull World Health Organ. 1997;75:81-93.

16. Tosun $S$, Batirel A, Oluk Al, Aksoy F, Puca E, Bénézit $F$, Ural $S$, NaymanAlpat S, Yamazhan T, Koksaldi-Motor V, Tekin R, Parlak E, Tattevin P, KartYasar K, Guner R, Bastug A, Meric-Koc M, Oncu S, Sagmak-Tartar A, Denk A, Pehlivanoglu F, Sengoz G, Sørensen SM, Celebi G, Baštáková L, Gedik H, Dirgen-Caylak S, Esmaoglu A, Erol S, Cag Y, Karagoz E, Inan A, Erdem H. Tetanus in adults: results of the multicenter ID-IRI study. Eur J Clin Microbiol Infect Dis. 2017;36:1455-62.

17. Williams WW, Lu PJ, O'Halloran A, Kim DK, Grohskopf LA, Pilishvili T, Skoff TH, Nelson NP, Harpaz R, Markowitz LE, Rodriguez-Lainz A, Fiebelkorn AP. Surveillance of Vaccination Coverage among Adult Populations - United States, 2015. MMWR Surveill Summ. 2017;66:1-28.

18. Razzaghi R, Khalifesoltani A, Heravi MM, Akbari H. Tetanus immunity in individuals aged 50 years or older in Kashan, Iran. Acta Med Iran. 2011;49:379-82.

19. Oncü $S$, Onde $M$, Ergin $F$, Oztürk B. Tetanus seroepidemiology and factors influencing immunity status among farmers of advanced age. Health Policy. $2011 ; 100: 305-9$

20. Karabay 0, Ozkardes F, Tamer A, Karaarslan K. Tetanus immunity in nursing home residents of Bolu, Turkey. BMC Public Health. 2005;5:5.

21. Tanriover D, Soyler C, Ascioglu S, Cankurtaran M, Unal S. Low seroprevalance of diphtheria, tetanus and pertussis in ambulatory adult patients: the need for lifelong vaccination. Eur J Intern Med. 2014;25:528-32.

22. Kader Ç, Balci M, Erbay A. Evaluation of tetanus antibody levels in adults in Yozgat, Turkey. Turk J Med Sci. 2016;46:646-50.

23. Oztürk A, Göahmetoğlu $S$, Erdem F, Misgüroğlu S. Tetanus antitoxin levels among adults over 40 years of age in Central Anatolia, Turkey. Clin Microbiol Infect. 2003;9:33-8.

24. Coplu N, Esen B, Gozalan A, Kurtoglu D, Ishid S, Miyamura K. Immunity against tetanus and effect of vaccination in Turkey. Scand J Infect Dis. 2006;38:1009-16

25. Farnworth E, Roberts A, Rangaraj A, Minhas U, Holloway S, Harding K. Tetanus in patients with chronic wounds - are we aware? Int Wound J. 2012;9:93-9. 